\title{
Body linear traits for identifying prolific goats
}

\author{
Avijit Haldar ${ }^{1}$, Prasenjit Pal ${ }^{2}$, Debasis Majumdar ${ }^{3}$, Chanchal K. Biswas ${ }^{3}$, Saurabh Ghosh $^{4}$ and Subhransu Pan ${ }^{5}$
}

1. Division of Animal Reproduction, ICAR Research Complex for North Eastern Hill Region, Tripura Centre, Agartala, Lembucherra- 799210, West Tripura, India; 2. Department of Fisheries Extension, College of Fisheries, Central Agricultural University, Lembucherra, West Tripura, India; 3. Faculty of Agriculture, Bidhan Chandra Krishi Viswavidyalaya, Mohanpur, Nadia, West Bengal, India; 4. Department of Biological Sciences, Human Genetics Unit, Indian Statistical Institute, Kolkata, West Bengal, India; 5. Department of Livestock Production Management, West Bengal University of Animal and Fishery Sciences, 37, K. B. Sarani, Kolkata, West Bengal, India.

Corresponding author: Avijit Haldar, e-mail: avijit_vet@rediffmail.com, PP: prasenjit3agstat@gmail.com,

DM: debstat@gmail.com, CKB: chanchalkanti@yahoo.co.in, SG: saurabh@isical.ac.in, SP: span28@rediffmail.com

Received: 18-07-2014, Revised: 06-11-2014, Accepted: 13-11-2014, Published online: 18-12-2014

doi: 10.14202/vetworld.2014.1103-1107. How to cite this article: Haldar A, Pal P, Majumdar D, Biswas CK, Ghosh S, Pan S (2014) Body linear traits for identifying prolific goats, Veterinary World 7(12): 1103-1107.

\begin{abstract}
Aim: The present study was conducted on prolific goat breed to identify body linear type traits that might be associated with prolificacy trait in goats.

Materials and Methods: Two-stage stratified random sample survey based data were collected from 1427 non-pregnant goats with the history of single, twin and triplet litter sizes (LZ) between January 2008 to February 2011 for 3 years in 68 villages located in East and North East India. Data on sixteen body linear traits were analyzed using logistic regression model to do the step-wise selection for identifying the body linear traits that could determine LZ. An average value for each identified body linear trait was determined for classifying the goats into three categories: Goats having the history of single LZ, goats having the history of twin LZ and goats having the history of triplet LZ.

Results: The LZ proportions for single, twin and triplet, were 29.50, 59.14 and $11.36 \%$, respectively, with the prolificacy rate of $181.85 \%$ in Indian Black Bengal goats. A total of eight body linear traits that could determine LZ in prolific goats were identified. Heart girth (HG) measurement $(>60.90 \mathrm{~cm})$, paunch girth $(\mathrm{PG})(>70.22 \mathrm{~cm})$, wither height $(\mathrm{WH})(>49.75 \mathrm{~cm})$, neck length $(>21.45 \mathrm{~cm})$, ear length $(>12.80 \mathrm{~cm})$ and distance between trochanter major $(\mathrm{DTM})$ bones $(>12.28 \mathrm{~cm})$, pelvic triangle area (PTA) $\left(>572.25 \mathrm{~cm}^{2}\right)$ and clearance at udder $(\mathrm{CU})(>23.16 \mathrm{~cm})$ showed an increase likelihood of multiple LZ when compared to single LZ. Further, HG measurement $(>62.29 \mathrm{~cm})$, WH $(>50.54 \mathrm{~cm})$, PG $(>71.85 \mathrm{~cm})$ and ear length $(>13.00 \mathrm{~cm})$, neck length $(>22.01 \mathrm{~cm})$, PTA $\left(>589.64 \mathrm{~cm}^{2}\right)$, CU $(>23.20 \mathrm{~cm})$ and DTM bones $(>12.47 \mathrm{~cm})$ were associated with increased likelihood of triplet LZ, when compared with that of twin LZ.
\end{abstract}

Conclusion: HG measurement was the best discriminating factor, while PG, neck length, DTM bones, CU, PTA, WH and ear length measurements were other important factors that could be used for identifying prolific goats to achieve economic benefit out of prolificacy trait.

Keywords: Black Bengal, body linear traits, goat, prolificacy, litter size.

\section{I ntroduction}

Prolificacy is an important economic trait in small ruminants like goats on which millions of resource - limited rural populace and economically weaker sections of the society depend for their livelihoods in developing countries like India, Bangladesh and other Southeast Asian countries. Thus, more kid production is of great interest to goat producers to meet the huge demand of goat meat in India as well as in other Asian countries [1]. Black Bengal goat is a native, well adopted, small-sized and meattype breed in eastern and north-eastern regions of India [2] and in Bangladesh [3]. This goat breed is famous for its quality of meat and leather with high prolificacy rate [4]. However, it is not known which one is prolific in Black Bengal goat population

Copyright: The authors. This article is an open access article licensed under the terms of the Creative Commons Attributin License (http:// creative commons.org/licenses/by/2.0) which permits unrestricted use, distribution and reproduction in any medium, provided the work is properly cited. spread over its breeding tract. It is, thus, essential to find out the prolific one from the population of a specific breed for exploiting kid production potential. Recently, we used gonadotrophin-releasing hormone challenge test to examine prolificacy potential in goats [5]. Few descriptive linear traits that might be useful and farmers' friendly tools for the discrimination between the goats carrying multiple fetuses and the goats carrying single fetus and thus, achieving more economic benefits out of multiple births by taking special care of the pregnant goats carrying multiple fetuses have been identified recently [6]. Although, there is still limited application of genetic evaluation of livestock species in developing countries, linear traits have currently been included in the genetic evaluations of a variety of breeds of goats in the United States of America [7]. There is inadequate information on the association between linear traits and fertility traits in goats [8]. We thus aimed to identify body linear type traits that might be associated with prolificacy trait in goats. 


\section{Materials and Methods}

\section{Ethical approval}

The experimental protocol and animal care were met in accordance with the National guidelines for care and use of Agricultural Animals in Agricultural Research and Teaching.

\section{Study area and experimental animals}

The study area included 45 villages in 4 districts (Nadia, North 24 paraganas, Hooghly and Murshidabad) of West Bengal, a state of Eastern India and 23 villages in 3 districts (West Tripura, South Tripura and Dhalai) of Tripura, a state of North - East India. These seven districts are part of the Black Bengal goat breeding tract in the country (Figure-1). The climate is hot and humid with temperature ranging from $9^{\circ} \mathrm{C}$ in winter to $40^{\circ} \mathrm{C}$ in summer with annual rainfall ranging from $1500 \mathrm{~mm}$ to $2000 \mathrm{~mm}$. Two-stage stratified random sample survey (consisting of village as strata-1 and animal within village as strata-2) based data were collected from 1427 non-pregnant goats with the history of single, twin and triplet litter sizes (LZ) between January 2008 to February 2011 for 3 years.

The Black Bengal goat breed was the experimental animal in the present study. The goats were generally reared in small numbers from 2 to 5 per household under the free range system on natural vegetation and tree lopping without any supplementation. Nonpregnant goats that were apparently free from diseases, experienced at least two kidding, but not completed their sixth kidding, were selected randomly in the villages for collecting data on various linear traits. The history of LZ, age, and parity of each goat, as reported by the owner, was noted. LZ was defined as the number of kid(s) born to each goat and considered at 3 levels: Single, twin and triplet births.

\section{Data collection procedure and description}

Sixteen16 body linear traits recorded included ear length, neck length, head rump length, head rump curve length, body length, sacral length, body weight

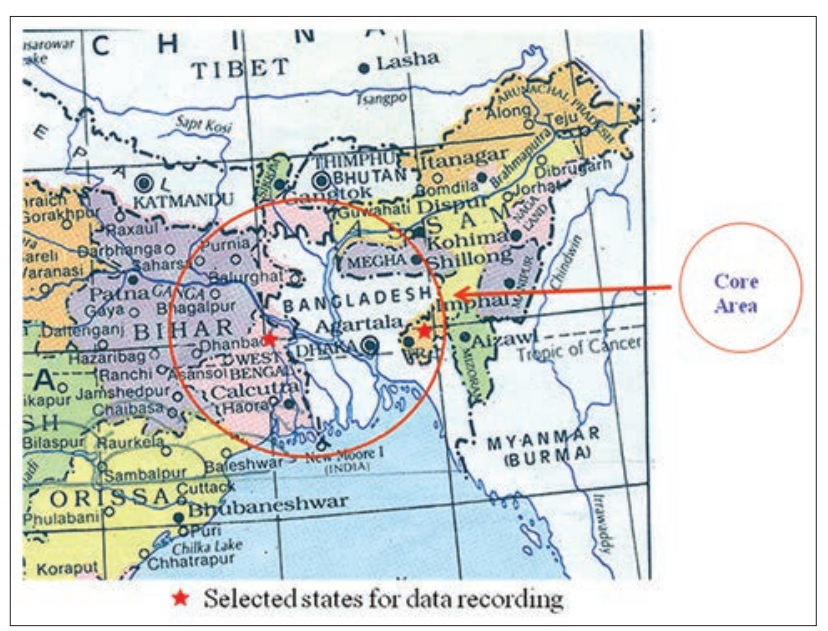

Figure-1: Breeding tract of meat-type, prolific Indian Black Bengal goats.
(BW), heart girth (HG), paunch girth (PG), pelvic triangle area (PTA), wither height (WH), croup height, clearance at sternum, clearance at udder (CU), distance between tuber coxae bones (DTC) and distance between trochanter major bones (DTM). The length, height and circumference measurements (centimeters) were taken using a measuring tape. The measurements (centimeters) of DTC and DTM were done using a calibrated wooden caliper. BW (kg) was taken using a spring balance. All measurements were recorded on an individual data sheet from the non- pregnant goats in the morning before the animals were released for grazing. Each individual goat was sampled once only.

\section{Statistical analysis}

Data were analyzed in four steps. In the first step, PROC LOGISTIC; SAS 9.3, 2012, has been employed to fit a two-way Logit, which models the probability of $\mathrm{LZ}(\mathrm{LZ}=0)$ with location effect. The location effect was not statistically significant $(\mathrm{p}=0.3736)$ as shown in Table-1. Thus, there was no evidence of the location effect on LZ of goat. Hence, the data recorded on 1427 goats in two locations, viz. West Bengal and Tripura were pooled together and subjected to the second step analysis using multiple stepwise logistic forward regressions (PROC LOGISTIC; SAS 9.3, 2012) to do the stepwise selection for identifying the prognostic factors for LZ. The model used was the logistic regression (LR) model:

$$
\log \left[\frac{\theta(x)}{1-\theta(x)}\right]=\alpha+\beta_{1} x_{1}+\beta_{2} x_{2}+\ldots+\beta_{i} x_{i}
$$

where, all body linear traits measured were considered independent variables that were represented by ' $x$ ', the resultant LZs were the dependent, predictor variables, $\alpha$ =intercept of the model and $\beta=$ the coefficient of predictor variables

LR enters predictor variables in a stepwise manner; it will also fit specified models or perform forward selection of variables. At each step in the stepping process, an attempt was made to remove any insignificant variables from the model before adding a significant variable to the model. A significance level of 0.3 was required to allow a variable to enter into the model, and a significance level of 0.35 was required for a variable to stay in the model. The step selection was based on the maximum likelihood ratio. The evaluation of the logistic regression model was done by Hosmer and Lemeshow Goodness-of-Fit Test in the logistic procedure.

The response variable chooses $L Z=1$ (when a goat having the history of more than one $\mathrm{LZ}$ ) as against $\mathrm{LZ}=0$ (when a goat having the history of single $\mathrm{LZ}$ ), so that the probability of $\mathrm{LZ}$ is modeled.

Table-1: Logistic procedure: Analyze of effects.

\begin{tabular}{lccc}
\hline Effect & Wald Chi square & df & Pr. $>$ Chi square \\
\hline Location & 0.7917 & 1 & 0.3736 \\
\hline
\end{tabular}


Table-2: Indian Black Bengal goats with different LZ groups and prolificacy

\begin{tabular}{|c|c|c|c|c|c|c|}
\hline & \multicolumn{3}{|c|}{ LZ } & \multirow{2}{*}{$\begin{array}{c}\text { Total } \\
\text { kids born }\end{array}$} & \multirow{2}{*}{$\begin{array}{l}\text { Average kid } \\
\text { born/ doe }\end{array}$} & \multirow{2}{*}{$\begin{array}{c}\text { Prolificacy } \\
(\%)\end{array}$} \\
\hline & Single & Twin & Triplet & & & \\
\hline Number of animal $(n=1427)$ & 421 & 844 & 162 & 2595 & 1.81 & 181.85 \\
\hline$\%$ of animal & 29.50 & 59.14 & 11.36 & & & \\
\hline
\end{tabular}

$\mathrm{LZ}=$ Litter size

From stepwise logistic regressions, some traits were emerged as the prognostic factors that could influence LZ significantly.

In the third step, we wanted to find out certain point of measurement of various identified factors that could indicate the likelihood of multiple LZ in goats. The average value for each identified (stepwise logistic procedure) body linear trait was determined for classifying the goats into one of the two categories of identified traits: Those above or below average value for each trait. The null hypothesis that odds of prolificacy (goats having the history of twin or triplet LZ vs. goats having the history of single LZ) is the same in goats classified as above or below average for different identified body linear traits was tested by using logistic regression model (PROC LOGISTIC; SAS 9.3, 2012). The identified potential traits associated with LZ were included in the model as independent variables. The resulting values (odds ratios) were then interpreted as a decisive factor. An odd ratio of ' 1 ' indicates that the factor examined does not alter the chance of single or multiple LZs. Odd ratios $>1$ imply a direct association with an increased likelihood of multiple LZs. Odd ratios $<1$ imply an inverse association with the likelihood of multiple LZs.

Finally, an average value for each identified body linear trait was determined for classifying the goats having the history of multiple LZs into one of two categories (goats having the history of triplet LZ vs. goats having the history of twin LZ) using logistic regression model (PROC LOGISTIC; SAS 9.3, 2012) as mentioned above. Odd ratios $>1$ imply a direct association with an increased likelihood of triplet LZ, while odd ratios $<1$ imply an association with the likelihood of twin LZ.

\section{Results and Discussion \\ Prolificacy}

The percent of Black Bengal does show different birth type based on LZ presented in Table-2. The LZ proportions for single, twin and triplet, were 29.50, 59.14 and $11.36 \%$, respectively. The prolificacy rate was recorded as $181.85 \%$, registering on an average of 1.81 kids per goat. The average LZ being 1.81 in this study is quite comparable with some world prolific goat breeds like Nubian, Pygmy, American Alpine, French Alpine, Saanen and Toggenburg with the average LZ of 2.0, 1.9, 1.9, 1.7, 1.7 and 1.6, respectively [9].

\section{Association of body linear traits with LZ}

Descriptive statistics for different body linear traits, including age and parity in Black Bengal goats
Table-3: Descriptive statistics for different body linear traits including age, parity in Indian Black Bengal goats.

\begin{tabular}{lc}
\hline Trait & Mean \pm SD \\
\hline Age (month) & $25.87 \pm 10.47$ \\
Parity (number) & $2.78 \pm 1.21$ \\
Ear length $(\mathrm{cm})$ & $12.80 \pm 1.51$ \\
Neck length $(\mathrm{cm})$ & $21.45 \pm 3.89$ \\
BW $(\mathrm{kg})$ & $17.36 \pm 4.31$ \\
HRL $(\mathrm{cm})$ & $58.42 \pm 6.01$ \\
HRCL $(\mathrm{cm})$ & $63.30 \pm 5.97$ \\
BL $(\mathrm{cm})$ & $54.09 \pm 5.69$ \\
SL $(\mathrm{cm})$ & $13.25 \pm 1.53$ \\
WH $(\mathrm{cm})$ & $49.75 \pm 4.41$ \\
CH $(\mathrm{cm})$ & $52.15 \pm 4.56$ \\
HG $(\mathrm{cm})$ & $60.90 \pm 5.84$ \\
PG $(\mathrm{cm})$ & $70.22 \pm 7.09$ \\
CU $(\mathrm{cm})$ & $23.16 \pm 3.62$ \\
CS $(\mathrm{cm})$ & $24.90 \pm 3.00$ \\
PTA $(\mathrm{square} \mathrm{cm})$ & $572.25 \pm 193.93$ \\
DTC $(\mathrm{cm})$ & $11.00 \pm 1.33$ \\
DTM $(\mathrm{cm})$ & $12.28 \pm 1.25$ \\
\hline HRCL &
\end{tabular}

$\mathrm{HRCL}=$ Head rump curve length, $\mathrm{PG}=$ Paunch girth, $\mathrm{HG}=$ heart girth, $\mathrm{CU}=$ Clearance at udder, $\mathrm{CS}=$ Clearance at sternum, PTA $=$ Pelvic triangle area, DTC $=$ Distance between tuber coxae bones, DTM=Distance between trochanter major bones, $\mathrm{BL}=$ Body length, $\mathrm{WH}=$ Wither height, $\mathrm{SL}=\mathrm{Sacral}$ length, $\mathrm{CH}$ : Croup height, HRL: Head rump length, BW: Body weight, SD: Standard deviation

Table-4: Summary of stepwise logistic selection of various body linear traits influencing LZ in Indian Black Bengal goats.

\begin{tabular}{llccc}
\hline Step & $\begin{array}{l}\text { Effect } \\
\text { entered }\end{array}$ & DF & $\begin{array}{c}\text { Score } \\
\text { Chi-square }\end{array}$ & Pr.>Chi square \# \\
\hline 1 & HG & 1 & 193.91 & $<0.0001$ \\
2 & PG & 1 & 10.77 & 0.0010 \\
3 & Neck length & 1 & 9.55 & 0.0020 \\
4 & DTM & 1 & 5.44 & 0.0196 \\
5 & CU & 1 & 2.55 & 0.1101 \\
6 & PTA & 1 & 4.31 & 0.0378 \\
7 & WH & 1 & 2.11 & 0.1460 \\
8 & Ear length & 1 & 1.55 & 0.2130 \\
\hline
\end{tabular}

\# The Pr.>Chi square is 0.2423 at $8 \mathrm{df}$ and value of Chi square is 10.3344 as per Hosmer and Lemeshow Goodness- of-Fit test, $P G=$ Paunch girth, $H G=$ heart girth, $\mathrm{CU}=$ Clearance at udder, PTA=Pelvic triangle area, DTM=Distance between trochanter major bones, $\mathrm{WH}=$ Wither height, $\mathrm{LZ}=$ Litter size

are presented in Table-3. A total of eight body linear traits out of 16 traits were identified through stepwise logistic selection as presented in Table-4. The results of the Hosmer and Lemeshow test register the goodness-of-fit of the selected logistic regression model where 0.2423 is a probability value (Table-4). HG measurement was the best discriminating factor between goats having the history of multiple LZs and 
goats having the history of single LZ. PG, neck length, DTM bones, CU, PTA, WH and ear length measurements were other important factors that could influence LZ. Though some genes have been identified for influencing LZ in goats [10-12], certain body condition score, higher live weight, physical strength and less slopped rump angles have been implicated in an increase likelihood of multiple births in does $[8,13]$ and in ewes [14,15].

Table 5 lists the body linear traits that influenced LZs (single vs. multiple) in Black Bengal goats based on the likelihood of LZ $>1$. HG measurement $(>60.90 \mathrm{~cm})$ was associated with four times increased likelihood of multiple LZ. Both PG $(>70.22 \mathrm{~cm})$ and $\mathrm{WH}(>49.75 \mathrm{~cm})$ registered three times more chances of multiple LZ when compared with that of single LZ. Neck length $(>21.45 \mathrm{~cm})$, ear length $(>12.80 \mathrm{~cm})$ and DTM bones $(>12.28 \mathrm{~cm})$ were associated with two times increased likelihood of multiple LZ. The goats with $>572.25$ square $\mathrm{cm}$ PTA and $>23.16 \mathrm{~cm}$ CU were 1.5 and 1.4 times more likely associated to have multiple LZ, respectively. Recently, we recorded an increased likelihood of bearing multiple fetuses for increase in somebody linear traits in pregnant goats due to enlargement of the body size during pregnancy to make room for twin or triplet fetuses [4]. Our present findings suggest that body linear traits may be the factors for differentiating the prolific goats having the potential of producing twin or triplet LZ from the non-prolific goats.

The body linear traits that influenced either twin or triplet LZ in Black Bengal goats are presented in Table-6. HG measurement $(>62.29 \mathrm{~cm})$ showed 4.4 times increased likelihood of triplet LZ when compared to twin LZ. WH $(>50.54 \mathrm{~cm})$, PG $(>71.85 \mathrm{~cm})$ and ear length $(>13.00 \mathrm{~cm})$ were associated with two

Table-5: Summary of logistic regression model of the influence of various body linear traits associated with LZs (single vs. multiple) in Indian Black Bengal goats.

\begin{tabular}{|c|c|c|c|c|c|c|}
\hline Parameter & $\begin{array}{l}\text { Cut-off } \\
\text { value }\end{array}$ & $\begin{array}{c}\text { Number } \\
\text { of animals }\end{array}$ & $\begin{array}{l}\text { Body linear trait } \\
(\text { mean } \pm \text { SD })\end{array}$ & $\begin{array}{l}\text { Odds ratio } \\
\text { estimate }\end{array}$ & $\begin{array}{c}95 \% \text { wald } \\
\text { confidence limits }\end{array}$ & p value \\
\hline \multirow[t]{2}{*}{ HG } & $<60.90$ & 699 & $56.17 \pm 3.42$ & 1.000 & $3.257-5.347$ & $<0.0001$ \\
\hline & $>60.90$ & 728 & $65.44 \pm 3.67$ & 4.166 & & \\
\hline \multirow[t]{2}{*}{ PG } & $<70.22$ & 762 & $65.04 \pm 4.47$ & 1.000 & $2.808-4.651$ & $<0.0001$ \\
\hline & $>70.22$ & 665 & $76.16 \pm 4.36$ & 3.610 & & \\
\hline \multirow[t]{2}{*}{ Neck length } & $<21.45$ & 735 & $18.44 \pm 2.25$ & 1.000 & $1.631-2.604$ & $<0.0001$ \\
\hline & $>21.45$ & 692 & $24.65 \pm 2.45$ & 2.061 & & \\
\hline \multirow[t]{2}{*}{ DTM } & $<12.28$ & 816 & $11.44 \pm 0.72$ & 1.000 & $2.096-3.448$ & $<0.0001$ \\
\hline & $>12.28$ & 611 & $13.39 \pm 0.89$ & 2.688 & & \\
\hline \multirow[t]{2}{*}{$\mathrm{CU}$} & $<23.16$ & 858 & $20.84 \pm 1.90$ & 1.000 & $0.829-1.321$ & 0.6992 \\
\hline & $>23.16$ & 569 & $26.65 \pm 2.69$ & 1.407 & & \\
\hline \multirow[t]{2}{*}{ PTA } & $<572.25$ & 856 & $442.24 \pm 69.32$ & 1.000 & $1.209-1.949$ & 0.0004 \\
\hline & $>572.25$ & 571 & $767.15 \pm 153.11$ & 1.533 & & \\
\hline \multirow[t]{2}{*}{ WH } & $<49.75$ & 706 & $46.26 \pm 2.31$ & 1.000 & $2.409-3.891$ & $<0.0001$ \\
\hline & $>49.75$ & 721 & $53.18 \pm 3.08$ & 3.067 & & \\
\hline \multirow[t]{2}{*}{ Ear length } & $<12.80$ & 609 & $11.43 \pm 0.82$ & 1.000 & $1.636-2.597$ & $<0.0001$ \\
\hline & $>12.80$ & 818 & $13.81 \pm 1.03$ & 2.061 & & \\
\hline
\end{tabular}

$\mathrm{LZ}=$ Litter size, $\mathrm{PG}=$ Paunch girth, $\mathrm{HG}=$ heart girth, $\mathrm{CU}=$ Clearance at udder, $\mathrm{PTA}=$ Pelvic triangle area, DTM=Distance between trochanter major bones, $\mathrm{WH}=$ Wither height, $\mathrm{SD}=$ Standard deviation

Table-6: Summary of logistic regression model of the influence of various body linear traits on either twin or triplet LZ in Indian Black Bengal goats.

\begin{tabular}{|c|c|c|c|c|c|c|}
\hline Parameter & $\begin{array}{l}\text { Cut-off } \\
\text { value }\end{array}$ & $\begin{array}{l}\text { Number } \\
\text { of animals }\end{array}$ & $\begin{array}{l}\text { Body linear trait } \\
\text { (mean } \pm \text { SD) }\end{array}$ & $\begin{array}{l}\text { Odds ratio } \\
\text { estimate }\end{array}$ & $\begin{array}{c}95 \% \text { wald } \\
\text { confidence limits }\end{array}$ & p value \\
\hline \multirow[t]{2}{*}{ HG } & $<62.29$ & 530 & $58.26 \pm 3.26$ & 1.000 & 2.994-6.451 & $<0.0001$ \\
\hline & $>62.29$ & 475 & $66.79 \pm 3.42$ & 4.405 & & \\
\hline \multirow[t]{2}{*}{ PG } & $<71.85$ & 494 & $66.59 \pm 4.01$ & 1.000 & $1.686-3.448$ & $<0.0001$ \\
\hline & $>71.85$ & 511 & $76.94 \pm 4.29$ & 2.409 & & \\
\hline \multirow[t]{2}{*}{ Neck length } & $<22.01$ & 570 & $19.34 \pm 2.27$ & 1.000 & $1.142-2.247$ & 0.0062 \\
\hline & $>22.01$ & 435 & $25.52 \pm 2.33$ & 1.602 & & \\
\hline \multirow[t]{2}{*}{ DTM } & $<12.47$ & 525 & $11.55 \pm 0.70$ & 1.000 & $1.005-1.976$ & 0.0465 \\
\hline & $>12.47$ & 480 & $13.48 \pm 0.91$ & 1.408 & & \\
\hline \multirow[t]{2}{*}{$\mathrm{CU}$} & $<23.20$ & 601 & $20.81 \pm 1.93$ & 1.000 & $1.019-2.004$ & 0.0383 \\
\hline & $>23.20$ & 404 & $26.77 \pm 2.64$ & 1.428 & & \\
\hline \multirow[t]{2}{*}{ PTA } & $<589.64$ & 613 & $460.35 \pm 70.38$ & 1.000 & $1.082-2.132$ & 0.0156 \\
\hline & $>589.64$ & 392 & $791.83 \pm 154.47$ & 1.517 & & \\
\hline \multirow[t]{2}{*}{ WH } & $<50.54$ & 538 & $47.48 \pm 2.27$ & 1.000 & $1.834-3.717$ & $<0.0001$ \\
\hline & $>50.54$ & 467 & $54.08 \pm 2.82$ & 2.610 & & \\
\hline \multirow[t]{2}{*}{ Ear length } & $<13.00$ & 376 & $11.56 \pm 0.73$ & 1.000 & $1.536-3.367$ & $<0.0001$ \\
\hline & $>13.00$ & 629 & $13.87 \pm 1.03$ & 2.272 & & \\
\hline
\end{tabular}

$\mathrm{LZ}=$ Litter size, $\mathrm{PG}=$ Paunch girth, $\mathrm{HG}=$ heart girth, $\mathrm{CU}=$ Clearance at udder, $\mathrm{PTA}=$ Pelvic triangle area, DTM=Distance between trochanter major bones, WH=Wither height, $\mathrm{SD}=$ Standard deviation 
times increased likelihood of triplet LZ. Neck length $(>22.01 \mathrm{~cm})$ and PTA $(>589.64$ square $\mathrm{cm})$ registered 1.6 and 1.5 times more chances of triplet LZ, respectively; whereas both CU $(>23.20 \mathrm{~cm})$ and DTM bones $(>12.47 \mathrm{~cm})$ showed 1.4 times increased likelihood of triplet LZ, when compared with that of twin LZ. Thus, body linear traits may be useful indicators to differentiate the goats based on the ability of producing twin or triplet LZ. Different linear traits have been suggested to be valuable tools in breeding programs for some likelihood of productive and reproductive traits in goats [7], in sheep [16] and in dairy cattle [17], because of the moderate to high heritability of some linear traits [18].

\section{Conclusions}

The present study generates the basic measurements of body linear traits in meat type, prolific breed like Black Bengal goats. The body linear traits could be used for identifying prolific goats to achieve economic benefit out of prolificacy trait.

\section{Authors' Contributions}

All authors contributed to conception and design of the study. Prasenjit Pal analyzed data. Avijit Haldar interpreted the results and drafted the article critically for important intellectual content. All authors evaluated and approved the article.

\section{Acknowledgment}

The authors would like to express their sincere thanks to Indian Council of Agricultural Research, New Delhi, India for providing financial assistance under National Fund for Basic, Strategic and Frontier Application Research in Agriculture (grant no. NFBSRA/PCN/AP-06/2006-07) to carry out the study. The authors wish to thank the farmers for their regular help and cooperation during the investigation in the field.

\section{Competing I nterests}

The authors declare that they have no competing interests.

\section{References}

1. Argüello, A. (2011) Trends in goat research, a review. $J$. Appl. Anim. Res., 39: 429-434.

2. Zeshmarani, S., Dhara, K.C., Samanta, A.K., Samanta, R. and Majumder, S.C. (2007) Reproductive performance of goats in eastern and north-eastern India. Livest. Res. Rural Dev., 19. Available from: http://www.lrrd.org/lrrd19/8/ zesh19114.htm. Last accessed on 28-10-2014.

3. Rahman, M.A., Rahman, S.M.M., Jalil, M.A., Nasiruddin, S. and Rahman, M.M. (2006) Molecular characterization of
Black Bengal and Jamunapari goat breeds by RAPD markers. Am. J. Anim. Vet. Sci., 1: 17-22.

4. Haldar, A., Pal, P., Datta, M., Paul, R., Pal, S.K., Majumdar, D., Biswas, C.K. and Pan, S. (2014) Prolificacy and its relationship with age, body weight, parity, previous litter size and body linear type traits in meat-type goats. Asian Aust. J. Anim. Sci. 27(5): 628-634.

5. Haldar, A., Pal, S.K., Chakraborty, S., Hazorika, M., Pan, S., Majumdar, D., Biswas, C.K., Patra, A., Mirmahmoudi, R. and Prakash, B.S. (2013) Endocrine markers for identifying prolificacy potential and predicting fetal number in goats. Anim. Reprod. Sci., 140(1-2): 54-61.

6. Pan, S., Biswas, C.K., Majumdar, D., Sengupta, D., Patra, A., Ghosh, S. and Haldar, A. (2014) Influence of age, body weight, parity and morphometric traits on litter size in prolific Black Bengal goats. J Appl. Anim. Res. DOI:10.108 0/09712119.2014.928623,

7. Wiggans, G.R. and Hubbard, S.M. (2001) Genetic evaluation of yield and type traits of dairy goats in the United States. J. Dairy Sci., 84: E69-E73.

8. Mellado, M., Mellado, J., Valencia, M. and Pittroff, W. (2008) The relationship between linear type traits and fertility traits in high-yielding dairy goats. Reprod. Domes. Anim., 43(5): 599-605.

9. Amoah, E.A., Gelaye, S., Guthrie, P. and Rexroad, C.E. (1996) Breeding season and aspects of reproduction of female goats. J. Anim. Sci., 74(4): 723-728.

10. An, X.P., Han, D., Hou, J.X., Li, G., Wang, J.G., Yang, M.M., Song, Y.X., Zhou, G.Q., Wang, Y.N., Ling, L., Yan, Q.M. and Cao, B.Y. (2009) GnRH gene polymorphisms and their effects on reproductive performance in Chinese goats. Small Rumin. Res., 85: 130-134.

11. Chu, M.X., Wu, Z.H., Feng, T., Cao, G.L., Fang, L., Di, R., Huang, D.W., Li, X.W. and Li, N. (2011) Polymorphism of GDF9 gene and its association with litter size in goats. Vet. Res. Commun., 35(6): 329-336.

12. Feng, T., Geng, C.X., Lang, X.Z., Chu, M.X., Cao, G.L., Di, R., Fang, L., Chen, H.Q., Liu, X.L. and Li, N. (2011) Polymorphisms of caprine GDF9 gene and their association with litter size in Jining Grey goats. Mol. Biol. Reprod., 38(8): 5189-5197.

13. Constantinou, A. (1989) Genetic and environmental relationships of body weight, milk yield and litter size in Damascus goats. Small Rumin. Res., 2: 163-174.

14. Gaskins, C.T., Snowder, G.D. and Westman, M.K. (2005) Influence of body weight, age and weight gain on fertility and prolificacy in four breeds of ewe lambs. J. Anim. Sci., 83(7): 1680-1689.

15. Aliyari, D., Moeini, M.M., Shahir, M.H. and Sirjani, M.A. (2012) Effect of body condition score, live weight and age on reproductive performance of Afshari ewes. Asian $J$. Anim. Vet. Adv., 7: 904-909.

16. Snowder, G.D. (2002) Composite trait selection for improving lamb production. Sheep Goat Res., 17: 42-49.

17. Royal, M.D., Pryce, J.E., Woolliams, J.A. and Flint, A.P.F. (2002) The genetic relationship between commencement of luteal activity and calving interval, body condition score, production, and linear type traits in Holstein-Friesian dairy cattle. J. Dairy Sci., 85: 3071-3080.

18. Luo, M.F., Wiggans, G.R. and Hubbard, S.M. (1997) Variance component estimation and multitrait genetic evaluation for type traits of dairy goats. J. Dairy Sci., 80(3): $594-600$ 